\title{
Przysłowia ludowe i ich kontekst kulturowy w odniesieniu do żywności i żywienia w arabskich dialektach Āzah i Mārdīn'
}

\section{The folk proverbs and their cultural context in relation to food and nutrition in the Arabic dialects of Āzah and Mārdīn}

\author{
Michael Abdalla \\ INSTYTUT JĘZYKOZNAWSTWA, UNIWERSYTET IM. ADAMA MICKIEWICZA \\ AL. NIEPODLEGŁOŚCI 4, 61-874 POZNAŃ \\ masatur@amu.edu.pl
}

\begin{abstract}
This draft is an attempt to group and analyze the content of maxims, expressions, utterances, phrases, aphorisms and formulations which refer - directly or indirectly - to agriculture and raising animals as well as to the widely understood traditions and the culture of feeding among the inhabitants of the two ancient Assyrian towns in southeastern Turkey: Āzah and Mārdīn. This type of folk prose is very popular in the Middle East. Even though the procurement of food and the preparation of meals belong likely to the most important human cares and take most of the time particularly of the populations living in villages, the group of proverbs concerning the analyzed topic in each collection is only about $8 \%$ of the total.
\end{abstract}

\section{Krótki opis miejscowości}

Āzah (Hāzah̆, Āzəx, Azëx, Asex, Bāzəbde, dziś İdil) jest miasteczkiem, od czasów starożytnych zamieszkałym przez ludność asyryjską. W odwecie za wyjątkowo dzielny opór stawiany przez mieszkańców w latach ludobójstwa dokonanego przez Turków i Kurdów na Ormianach i Asyryjczykach (19141918), miasteczko zostało odcięte od świata. Pozbawieni środków do życia mieszkańcy mieli do wyboru śmierć głodową albo masowy exodus. Exodus nastąpił w 1964 roku. Dziś na blisko pięć tysięcy mieszkańców, głównie Kurdów, Asyryjczycy stanowią mniej niż o,5\% (Abdalla 2008: 59-77).

${ }^{1}$ Obie miejscowości leżą w południowo-wschodniej Turcji. Autorami zbiorów przysłów byli, kolejno: Ishāa L. (1994) (ur. w Āzahn, 1938 - jego zbiór zawiera 1370 ponumerowanych przysłów) i Bār Armaltō I. (1927) (ur. w Mārdīnie, 1879 - jego zbiór obejmuje około 1100 przysłów bez numeracji). Holocaust zmusił obu do wychodźstwa; L. Isḥāq zakończył swój żywot w Syrii (2011), a I. Bār Armaltō w Libanie (1954) i w tych krajach wydawali oni swoje dzieła w językach arabskim i asyryjskim. Dla przejrzystości mārdińskie zwroty ujęto w przypisach. 
Mārdīn (Mardin, Mērdīn, Mərde) leży w odległości około 100 km na zachód od Āzah. Do I wojny światowej chrześcijanie (Asyryjczycy i Ormianie) stanowili co najmniej połowę mieszkańców blisko dwudziestotysięcznego wówczas miasta. Obecnie miejscowość liczy około 100 tysięcy mieszkańców, w tym nie więcej niż 100 rodzin asyryjskich i ormiańskich razem. W roku 2007 powstał w mieście aktywnie działający Mardin Artuklu Üniversitesi i uruchomiono lotnisko krajowe. Nieopodal miasta znajduje się znany asyryjski klasztor Za'farān (Szafranowy), będący przez wiele stuleci (do roku 1933) siedzibą patriarchy Syryjskiego Kościoła Ortodoksyjnego Antiochii (Abdalla 2013: 131-142).

Nie jest wiadomo od kiedy mieszkańcy obu miejscowości posługują się specyficzną odmianą dialektu arabskiego. Prawdopodobnie ten proces zaczął się od podboju arabskiego w VII wieku. Rodzimy język asyryjski (syriacki) zachował się jedynie w liturgii. O ile w Āzah słyszy się obecnie prawie wyłącznie kurdyjski dialekt kurmanğī, mardiński dialekt arabski jest nadal żywy. Obu dialektom poświęcono wiele opracowań, także książkowych (Socin 1904, Jastrow 1969: 29-59, Wittrich 2001, Maqsi 2011)². I jak w przypadku każdego języka używanego w mowie na co dzień, także w dialektach Āzah i Mārdīn występuje bogactwo przysłów ludowych o różnorakiej tematyce.

\section{Przysłowie - próba definicji}

Kultura kształtuje się w obrębie ściśle określonego obszaru geograficznego nie bez wpływu uwarunkowań historycznych. Związane $\mathrm{z}$ nią przysłowia zawierają specyficzne metafory, zwroty semantyczne, charakterystyczne symbole, obrazy i przestrogi mające odniesienia do zmieniającej się sytuacji społecznej wspólnoty. Przesłaniem ich autorów jest zacieśnienie relacji międzyludzkich, a poprzez wyciąganie wniosków z przeszłości wytyczają sposób postępowania $\mathrm{z}$ sąsiadami $\mathrm{w}$ różnych okolicznościach, zgodnie $\mathrm{z}$ odziedziczonym modelem.

Przysłowia są skarbnicą ludowej literatury narodowej, kwintesencją zmagań i doświadczeń wielu pokoleń. Utrwalone w pamięci odzwierciedlają zbiorową mądrość i myśli, postawy i poglądy, swoistą wizję, obyczaje i wierzenia. Są wierną ilustracją zalet i przywar członków wspólnoty, wyznacznikiem osobowości, tożsamości i kultury, echem i znakiem związku z czasem. Dzięki zwięzłemu i ekonomicznemu sformułowaniu oraz lekkości i głębi treści, przysłowia uchodzą za najpopularniejszy środek wyrazu; w nich odbija się czysta retoryka. Ich znaczenie nie jest zależne od poziomu rozwoju cywilizacyjnego; bowiem każda grupa etniczna posiada swoje charakterystyczne przysłowia organicznie związane $\mathrm{z}$ jej historią, geografią $\mathrm{i}$ warunkami bytowania.

\section{Wyrazy nawiązujące do rolnictwa, hodowli, żyw- ności i żywienia}

2 17-19 maja 2013 roku w Mardin Artuklu Üniversitesi odbyła się pierwsza konferencja poświęcona mówionym w Turcji dialektom arabskim. Honorowym gościem był znany prof. Otto Jastrow. Swój wykład inauguracyjny wygłosił w czystym dialekcie mārdińskim. 
W zbiorze przysłów z Āzah spotykamy nazwy następujących surowców i środków spożywczych (w ujęciu alfabetycznym)3: 'adas (soczewica), 'ağin (ciasto), 'asal (miód), 'asìde4, 'onəb (winogrona), bașal (cebula), batțīh (melony), bātōye5, ḅayz (jajka), dəhən (tłuszcz), zabaš (arbuzy), ğawze (orzech), ğəbne (ser), ğèğ (kury), halīb (mleko), həmmoș (ciecierzyca), hənța ${ }^{6}$ (pszenica), hamīe (drożdże, zakwas), ḩbayz (chleb), h̆honzīr (wieprz), h̆zzra (warzywa, zielenina), laban (jogurt), lah̆əm (mięso), pərpāre (portulaka), rìğf (bochenek), rəzz (ryż), samake (ryba), səkkar (cukier), sūm (czosnek), šìir (jęczmień), sfêro7, zafar (tłuszcz), zəbde (masło), zbīb (rodzynki); ze zwierząt hodowlanych: baqara (krowa), dīk (kogut), ganame (owca), hșān (koń), șannōra (kot); z innych zwierząt: do$b b \bar{a} s^{8}$, ğamal (wielbłąd), sa'ālab (lisy), tẹer (ptak), zəbbēne (mucha); z części ciała ludzkiego: 'aẓm (kość), 'èn (oko), ğawf (brzuch, żołądek), 'ìd (ręka), qalb (serce), rās (głowa), rəkbe (kolano), səmm (usta), wəčč (twarz) zərs (ząb); ze smaków: hāməz (kwaśny), hulū (słodki), mərr (gorzki); ze sprzętu domowego i kuchennego: bardūše (garnek), dann (beczka, kocioł), dawq9 ${ }^{9}$ maǵrafe (nabierka), mah̆mara (dzieża do fermentacji), malaqa (łyżka, łyżeczka), mașara (zestaw z kamieni do wyciskania soku), mənšā (piła), qadah (kubek, szklanka), səfre (duża taca), səkkīn (nóż), șēniyye (mała taca), tannōr (piec); z części roślin: bəzər (nasiona), bōq (łodyga), smār (owoce); z czasowników związanych z gastronomią: akal (jeść), bala (połykać), barrad (chłodzić), halab (doić), haraq (spalić, przypalić), hașad (żąć), hammar (poddać ciasto fermentacji), hassar (poddać mleko fermentacji), $k a b b$ (wylać, wyrzucić), salaq (gotować, smażyć), šabba' (nasycić), šamm (wąchać), qaššar (obrać), qammar (zrumienić), mazag (żuć), nafah (dmuchać); z wyrazów związanych: akəl (jedzenie), 'ašă (kolacja), 'azāa (stypa), bāzār (targowisko, targowanie się), ğu'ān (głodny), ġadā (obiad), haš̌̌š (trawa), habbāz (piekarz), karm (winnica), loqme (kęs), nār (ogień), šărəb (pijący), šəb āan (najedzony), šəqfe (kawałek), šərbe (picie, łyk), šəv-

3 W arabskim dialekcie Āzah prawie całkowicie zniknęły głoski: „”, „d” i „d” - wszędzie, gdzie występują w klasycznym arabskim, wymawia się je kolejno: „s”, „z” i „z” bądź „z”, natomiast głoska „," w klasycznym arabskim wszędzie zamienia się w „z”.

4 Rodzaj deseru podobnego do budyniu.

5 Bātōye - ciasto w postaci placka, który odrywa się od ściany pieca chlebowego i spada do popiołu, zanim zostaje upieczony. Gospodyni podnosi je, czyści i ponownie przylepia do ściany pieca. Po upieczeniu dzielą się nim dzieci. Prawdopodobnie nazwa wzięła się od asyryjskiego wyrazu bețto, co oznacza iskrę ognia, która tworzy się w momencie zderzenia spadającego ciasta z żarem.

${ }^{6}$ To określenie spotyka się jedynie w dialektach $\mathrm{w}$ arabskich krajach azjatyckich. Wywodzi się $\mathrm{z}$ asyryjskiego wyrazu hẹte. $\mathrm{W}$ arabskim klasycznym i w krajach Maghrebu nazwa pszenicy brzmi qamh. Podobny wyraz, qamhō, oznacza w asyryjskim mąkę, proszek, miał. 7 Jajecznica. Nazwa pochodzi z asyryjskiego wyrazu esfiro [kula, piłka] (Tezel 2003: 14, 148, 256).

8 Pszczoły - z asyryjskiego dābōšè.

9 Asyryjskie dawqō [blacha - wypukła lub wklęsła]. Używa się jej najczęściej do wypieku naleśników. U Beduinów nosi nazwę săğ, podobnie jak nazwa wypieczonego na niej chleba plackowego z ciasta niepoddanego fermentacji (przaśnik). 
$\bar{a} n^{10}$, škavāi1 ${ }^{11} \bar{a} y \partial m$ (poszczący), tabha, tabīh (potrawa), zara' (sadzić, siać), zāq (spróbować); z nazw ludów: 'arab (Arabowie), 'oṣma!̣li (Osman).

\section{Wskazówki, rady, pouczenia}

Zebrane przysłowia dostarczają informacje, które odzwierciedlają stopień świadomości i wiedzy o środkach spożywczych. Jedne zawierają konkretne wskazówki i pouczenia o wpływie żywności na organizm i jego funkcjono-

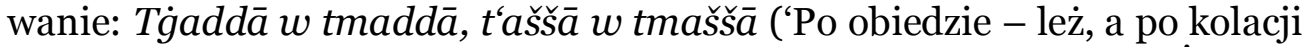
- pospaceruj')12. Inne potwierdzają sprawdzone teorie naukowe: $\dot{G} s$ l alfākha mon sammā $w$ hallì l-lahme fì dammā ('Umyj owoce $\mathrm{z}$ trucizn, a mięso zostaw z krwią)'13, Yākal rās rās l-haš̌̌š ('Jada wierzchnie części trawy') ${ }^{14}, S m \bar{a} r$ əd-dār t-tawwal all-ə-'mār ('Owoce własnego ogródka wydłużają życie'), Məsqāl lahım y-zayyə' alf 'aybe ('Naważka mięsa gubi tysiąc skaz')15, Ol-Hašš yrīd lo rašš ('Kto jada żarłocznie, potrzebuje dużo pić') ${ }^{16}$. W każdym przypadku sposób odżywiania się zależy od trybu życia i warunków klimatycznych: Kamā 'arab al mā rā hazra ('Niczym Arab, który nie widział warzyw') ${ }^{17}$.

Przysłowia przedstawiają galerię pouczeń o charakterze moralizatorskim, w konkretnym kręgu kulturowym nieograniczonych w miejscu i czasie. W jednym zwartym zdaniu podsumowuje się stuletnie praktyki wychowawcze. Ich przesłaniem jest m.in.: uregulowanie stosunków społecznych, wzmocnienie więzi solidarności, lojalności i zdrowych relacji miedzy członkami rodziny: Nês mō yqūl: laban̄ hāàmaz-we ('Nie wypada mówić:

10 Wyraz kurdyjski, pasterz.

${ }^{11}$ Kurdyjski - chleb przaśny, podobny do beduińskiego șāğ i asyryjskiego fātīīō.

12 Mardińska wersja wydaje się bardziej konkretna: Tg்addā $w$ tmaddā walaw ġafwətēn,

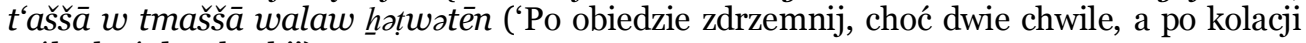
zrób choć dwa kroki’).

13 Tak samo brzmiące przysłowie znajdujemy u mieszkańców Mārdīnu. Niektóre gatunki dojrzałych owoców wydzielają substancje woskowe, do których mogą przylepić się owady. Owady zostawiają na wierzchu swoje wydzieliny i szkodliwe bakterie. Na owocach osiada także kurz z drobnoustrojami. Mięso zaś jest źródłem żelaza, pierwiastka występującego w krwi. Przysłowie ma chrześcijańską proweniencję; u muzułmanów potrawy zawierające krew są zakazane.

14 Przysłowie odnosi się do niektórych osób żyjących w dobrobycie i ma naukowe uzasadnienie: górne części rośliny jadalnej zawierają więcej składników lekkostrawnych od części dolnych, często zbutwiałych. Np. liście winorośli z końców pędów jada się w stanie surowym (mają kwaskowaty smak) i używa się powszechnie do przygotowania gołąbków, zamiast kapusty.

15 Zmniejsza chudość ciała, może też świadczyć o preferencji mięsa tłustego; tłuszcze sprzyjają tyciu. Choć dziś wiemy, że tycie nie jest zalecane, jednak w oczach mieszkańców regionu, gdzie zdecydowana większość była zajęta pracą fizyczną na roli, jest wyznacznikiem dobrobytu. Przede wszystkim tyje ten, kto mało pracuje fizycznie; gromadzone w organizmie kalorie nie spalają się.

16 Czasownik haššā oznacza ‘jeść dużo’ - tak określa się osoby, które obżerają się (Bašīr 1953: 97).

17 Odnosi się do osób, które jedzą łapczywie. Wzięto Beduinów za przykład, gdyż oni nie mają tradycji rolniczych i raczej nie uprawiają warzyw. Asyryjczycy i inne ludy osiadłe wykorzystują warzywa w kuchni na szeroką skalę, w postaci surowej, gotowanej, smażonej, suszonej, kiszonej. 
mój jogurt jest kwaśny’)18, Әzrəb w wağğð', ta“'mm $w$ šabbə'('Bij, aby zabolało, nakarm, aby się najadło')19, Zarb al-habīb - zbīb ('Bicie ukochanej osoby - rodzynki') ${ }^{20}$. Jednak Āzāh̄owie przyznają się do istnienia zachowań niepoprawnych, godnych ubolewania: Tola‘ mon al-ḅayza $w$ bazaq fiya ('Ledwie co opuścił jajko, a zaczął na nie pluć') ${ }^{21}$. A tego, kto nie docenia trudu i poświęcenia swoich bliskich, nie budzi zaufania i nie można na nim polegać, określa się: Kamā al-'adas: mālū wačč walā qafā ('Jest podobny do soczewicy, bez twarzy i potylicy'). Natomiast, kto odznacza się szlachetnością, honorem, godnością, męstwem, inteligencją i zdolnością do rozwiązywania problemów, jest godzien pochwały i zasługuje, aby być wzorem dla innych: Әd-Dīk al-fașīh man al-ḅayẓa yșīh ('Prawdziwy kogut od chwili opuszczenia jajka pieje')22. Obiektem potępienia są szczególnie egoiści, chytrzy, skąpi; w oczach wspólnoty są oni więźniami swojego jestestwa i sługami pieniądza. Śmieje się z nich, gdyż te cechy nie są z powodu biedy, lecz stanowią skazę psychiczną, która staje się nawykiem: Yəḥlab əzzabbēne ('On doi muchę'), Ǧāb șfêrtu la-bayza ('Do przygotowania jajecznicy ograniczył się do jednego jajka'), Laqmat al-garīb fi səmmu həlwe ('Kęs od obcych jest słodki w jego ustach'), Laqmatū b-mənniye ('Kęs od niego jest z łaski'), Aklū 'al-ğìrān w zartātū 'al-hịt dów, a purta na ściany'), Mən zbībāye yə‘mal máṣara ('Dla jednego rodzynka uruchamia zestaw do wyciskania soku')23. Słowem, w tych osobach spełnia się powiedzenie: Naqtat samm fi dann 'asal ('Kropla trucizny w beczce miodu'), czyli są odstępstwem od szlachetnego rodu. Takie naganne określenia nie obejmują tych, którzy żyją w trudnej sytuacji i nie ze swojej winy nie są w stanie zapewnić członkom rodziny wystarczającego pożywienia - o nich mówi się: Ol-Maraqa mā țāfat 'alayən ('Wywar nie wezbrał na nich'). Natomiast powiedzenie: Ğawfo wașlat ol-hoṣhăs ('Jego brzuch zrównał się z dnem') odnosi się do osób, które żyją w skrajnej biedzie. Nawet okoliczność związana z dorocznym cyklem pracy w winnicach, gdzie każdy mógł zerwać resztki winogron, określona Kamā yawm tašmīr al-

18 Występuje w zbiorze przysłów Mārdīnu: Maḥhad yqūl: labanī hāamậ we, z zastąpieniem wyrazu nēs wyrazem mahhad, który oznacza to samo.

19 Spotykamy je u mieszkańców Mārdīnu: Izā qatalt - wağğð', w izā ta “amt - šabbə' ('Jeśli uderzysz - niech zaboli; jeśli karmisz - do sytości’). Czasownik daraba ('uderzyć', 'bić') w dialekcie Mārdīnu jest zastąpiony czasownikiem qatala (w arabskim klasycznym: 'zabić').

2o W przysłowiach Mārdīnu występuje w formie rozbudowanej: Darb əl-habīb ğōz $w$ zbīb, $s \bar{a}^{‘} \bar{a}$ yəğ $a^{‘} w$ să'a yțīb ('Bicie ukochanego - orzechy i rodzynki: godzinę zaboli, a potem przestanie'). Na pamięć autora przywołuje powiedzenie powtarzane w latach dzieciństwa: „Konająca matka prosi swojego męża: «Jeśli po mojej śmierci poślubisz inną, proszę odciąć jedno z moich ramion, aby nim nowa matka uderzyła moje dzieci - będzie mniej bolało»".

${ }^{21}$ Takie same przysłowie usłyszymy od mieszkańców Mārdīnu.

22 W przysłowiach Mārdīnu występuje w identycznym brzmieniu.

23 Mārdīńska wersja: Man zbībāye yə’mal maỵhāne ('Z jednego rodzynka robi mayhāne’). Mayhāane - tak określano w języku tureckim miejsce, gdzie podawano napoje, potem znaczenie poszerzono na miejsca, gdzie podawano także jedzenie. Wyraz ma perskie pochodzenie. Wraz z podbojami osmańskimi upowszechnił się w krajach bałkańskich. 
kurūm (Jak w dniu pospolitego winobrania'), nie zapewni im wystarczających zapasów na zimę24.

Osoby źle mówiące o tych, którzy wyłącznie dzięki uczciwej pracy dobrze im się powodzi, fałszywie oskarżają, bo zazdroszczą im tego, co osiągnęli, wspólnota potępia: Ğawfən təğa' mənnū ('Mówiących o nim brzuch boli'25). Natomiast będący obiektem zazdrości i niesłusznych pomówień bywa określany: Ol-'Ālam təmzăg fi lahmo ('Ludzie żują jego mięso'). Postawa zrzędliwego, rozkapryszonego, marudnego i upartego, który dopóki nie otrzyma tego, co chce, nie przestanie domagać się natarczywie i nalegać - nieważne, czy jemu to się należy czy nie - zrodziła przysłowie: Hakā tșa!llat 'a-d-dīk, taytayla' bayza mənnū ('Jeśli się oprze, nawet z koguta wyciągnie jajko'), Ollī ykafzok rūhū, tayākal 'asīde ('Kto tarza się w ziemi, zje 'asīde'), Mahhhazū, ila tayla' zəbdətū ('Tak długo wytrząsał go, aż masło z niego wyciągnął') ${ }^{26}$. W przypadku symptomów obojętności, apatii i znieczulicy wobec bólu skazanych na bezradność i pokrzywdzonych przez los, braku oznak solidarności z nimi, niedzielenia się z potrzebującymi nadmiarem tego, co się posiada i nieudzielania schronienia, słyszy się powiedzenie: Әl-Ğawf əš-šəb'āne māla hāy mon al-ğūāne ('Syty nie zaprząta sobie głowy głodnym'). Jednak nie każdy żyjący we względnym dobrobycie, okre-

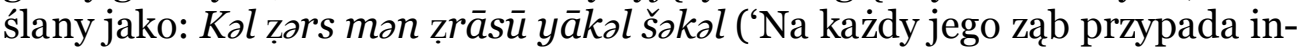
ny smak')27 albo Toțlab halīb et-tiyūr - tayğîb lək ('Nawet jeśli zapragniesz ptasiego mleka - przyniesie ci'), musi tak postępować. Natomiast o człowieku podstępnym, niewdzięcznym, zdradliwym, mówi się: Akkalnī laḥəm $w$ hallaqnī 'azəm ('Nakarmił mnie mięsem, wrzucił we mnie kością') ${ }^{28}$.

24 Taka akcja odbywała się pod koniec jesieni, po zbiorze winogron. Na krzewach winorośli wisiały niezauważone grona, niektóre z mało dojrzałymi owocami. Po ogłoszeniu dnia tašmīr chłopcy i dziewczęta kierowali się na teren winnic i zrywali znajdywane owoce. Miękkie zjadano na miejscu, a resztę, nazywaną 'ərməš, dosuszano na rodzynki. Oba wyrazy tašmīr i 'arməš wywodzą się z asyryjskich czasowników: šmāar i 'armēšs.

${ }^{25}$ Metafora 'brzuch boli' oznacza, że jest się zazdrosnym.

${ }^{26}$ Kafzak - położyć się na ziemi i obracać się w lewo i w prawo, aby wymusić ustępstwo. Czasownik hazz odnosi się do bukłaka, do którego wlewa się jogurt i wytrząsa aż tworzy się masło. Podobne sentencje znajdujemy w przysłowiach Mārdīnu: Yəšrab may, $w$ yqūl la nafsū haniyye ('Pije wodę i mówi do siebie: smacznego'), Șām səne w foțrr 'alā bașale ('Po

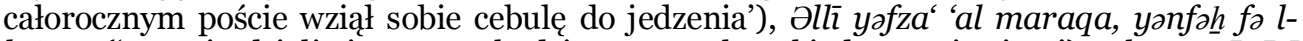
lahme ('Kto nie dzieli się sosem, będzie mu przykro, kiedy straci mięso'), Ol-Mansūurātī kəll yōm yūzən al-bayḍ ('Mieszkaniec Manșūriyye codziennie waży jajko'). Manșūriyye przed I wojną światową duża asyryjska wieś nieopodal Mārdīnu.

${ }_{27}$ Członek społeczności, który zdaje sobie sprawę, iż każdy żyje według swoich możliwości i nie narzeka na to, że obok mniej sytuowanych są też lepiej sytuowani, spełnia mardińskie przysłowia: Ol-Faqīr b-dəbsū wal-ġanī b-'asalū ('Biedny zadowoli się syropem, a bogaty - miodem'), A'da mən el-ġazāle mākū $w$ g̀èr nașībā mō tākal ('Szybszego [zwierzęcia] od gazeli nie ma, a ona zjada to, co jest jej przeznaczone').

${ }_{28}$ Podobne sytuacje mieszkańcy Mārdīnu wyrażają przysłowiami: Habbūnī ahlī lammā $k a \bar{a}$ fi darfi dəbəs $w$ bag̣dūnì lammā darfi yabəs ('Dopóki mój bukłak był pełen syropu, moi krewni lubili mnie. Kiedy się opróżnil, odwrócili się ode mnie'), Kuntu lahme - akalūnī, șartu 'adme - farrunī ('Byłem mięsem - zjedli mnie, stałem się kością - wyrzucili

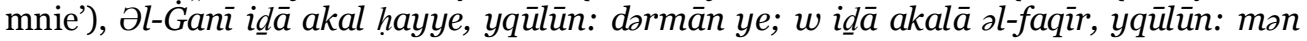
ğūo ('Jeśli bogaty zje węża, powiedzą: jest lekarstwem, a jeśli zje go biedny, powiedzą: z biedy'). Ostatni aforyzm pochodzi z apokryfu mędrcy Ahikara, doradcy i strażnika pieczęci asyryjskiego króla Sennaheriba i jego syna Asarhaddona (VIII-VII w. przed Chr.) (Dōla- 
Grupa przysłów stanowi przysłanie zachęcające do poczuwania się do odpowiedzialności wobec członków rodziny i mobilizuje do wytężonej pracy dla zapewnienia im środków do normalnego funkcjonowania, godnego i niekrępującego standardu życia, bez rozrzutności: Ol-Dabbar mā ğa $\bar{a}^{\prime} w a l-$ raqqa' $m \bar{a}$ ' 'ari ('Kto dobrze gospodaruje - nie głoduje, a kto łata - nie chodzi nago'), Hbayz al-gəddiye ${ }^{29}$ mō yšabbə' ('Chleb pochodzący z żebraniny nie daje uczucia pełnej sytości'), Hallī aklak w lā thallī šà glak ('Odłóż swoje jedzenie, ale nie odkładaj swojej pracy'), Lā ğall ən-nās yg்attī $w$ lā laqmətən tšabbə' ('Odzież obcych nie okrywa, ani ich kęs nie nasyci'), Bayz mā yənsələq fi zarțāt ('Purtaniem jajek nie ugotuje'), Baybūne mā təsī rabī‘so ('[Jeden] kwiat wiosny nie zrobi'), Mən dəhnū hatț 'alayū ('Ugotował [potrawę] w tłuszczu własnym [surowca]'). Z tymi przysłowiami koresponduje

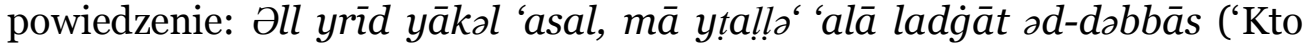
chce zjeść miód, nie przyjmuje się ukąszeniami pszczół'). Odwrotny sens do wyżej cytowanych mają dwa następujące przysłowia: Alla y a'ț alhəmməș ša l-mālu zrāas ('Bóg daje ciecierzycę tym, którzy nie mają zębów') i $M \bar{a}$ hatt šı 'an-nār ('Nic na ogień nie postawił') - słyszy się je w przypadku, kiedy komuś poszczęści się bez wysiłku i nie wie, jak te dobra wykorzystać i konsumować.

Na Bliskim Wschodzie sezon letni jest okresem wytężonej pracy zwłaszcza na obszarach wiejskich: m.in. zbiera się kolejne plony i przygotowuje się z nich zapasy na zimę. Zajęcie jest dla każdego, nawet dzieci biorą $\mathrm{w}$ tym udział. Odchylający się, który Bēn tammūz $w$ tabbah mā ysawìlū pāra ('Przez lipiec i sierpień nawet ułamka grosza nie zarobi')31, jest godny pożałowania i traci szacunek. Jednak każdy powinien wykonać to, co umie, aby nie mówiono: Mən əl-ȟzarra ğāb ot-țvor ${ }^{2}$ ('Ze wszystkich warzyw przyniósł jedynie rzodkiewki') i nie może on zapominać, że Ğabastēn b-'ìd wahde $m \bar{a}$ yənməskūn ('Dwóch arbuzów nie da się trzymać jedną ręką'). A przy wykonywaniu jakiejś czynności powinien zachować umiar i wyczucie i nie być nadgorliwym - wtedy nie usłyszy: Qəlna qammərū, mā qəlna hrrəqū ('Prosiliśmy o zrumienienie, nie o przypalenie'). Natomiast, kto nie zapewni sobie potrzebnych zapasów na zimę, wtedy może nawet Hasratū 'alā būq

bānī 1962). Asyryjski tekst o Ahikarze przetłumaczył na arabski Ġ.B. Behnām i wydało w Bagdadzie w 1976 roku Stowarzyszenie Języka Syriackiego. Arabską wersję przedrukowato czasopismo Ishtar, nr 1, s. 114-131, 1999 (Kanada). Polskie wydanie krytyczne wszystkich wersji językowych o Ahikarze, zob. Tronina (2011: 11-83).

29 O pochodzeniu wyrazu, prawdopodobnie z perskiego, pisze Tezel (2003: 83). Zarówno w dialektach arabskich, jak i w țūrabdīnskim, bardziej powszechna jest teraźniejsza forma czasownika, odpowiednio: $m g \bar{a} d \bar{e}$, ygaddī (żebrzeć).

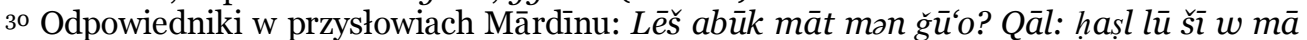
akal ('Dlaczego twój ojciec zmarł z głodu? Trafiło mu się coś [do jedzenia], ale nie skorzy-

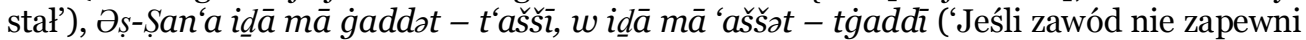
obiadu - zapewni kolację; jeśli nie zapewni kolacji - zapewni obiad'), nawet jeśli Mən əl'āzē $w$ al-lāzēe șăr hawwā̄s h̆həbbāzēe ('Potrzeba zmusza, aby być zbieraczem malwy'). Więcej o tej i innych roślinach dziko rosnących w kuchni, zob. Abdalla (2004: 50-58).

${ }^{31}$ Podobne sentencje przekazują powiedzenia mardińskie: Olli ygabbər - ydabbər ('Kto wcześniej orze, niczego mu nie zabraknie'), Bēẹat al-yōm ahsan mən dağāăğt ġad ('Jajko dzisiaj lepsze niż kura jutro').

32 Tavər, kurdyjska nazwa rzodkiewki, warzywa popularnego i taniego $\mathrm{w}$ regionie. 
basal ('Łodyga cebuli będzie dla niego nieosiągalna') i będzie musiał chodzić po domach i uprawiać żebraninę: Mən mgaddī la-mgaddī, lā y'ašš̄ wla ygaddī ('Od jednej żebraniny do drugiej; jego nie stać ani na obiad, ani na kolację').

Pomimo że do roku 1964 prawie wszyscy mieszkańcy Āzah byli chrześcijanami, zastanawia się stosunkowo skromna liczba przysłów odnoszących się do obyczajów chrześcijańskich - na ponad sto przysłów dotyczących tradycji żywieniowych znalazły się tylko cztery o tematyce chrześcijańskiej: Tưul mā al-hূanzīr șāyəm - əš-šəte dāyəm ('Dopóki świnia pości, trwa zima')33; Mā yəzhak la-bayzat ol-`id ('Nie uśmiecha się nawet do jajka wielkanocnego'), czyli jest ponury i prawie z niczego się nie cieszy; olli yəskar - mā y'ədd al-la-qdāh ('Kto się upija, nie liczy, ile wypił'), czyli należy być wytrwałym, pokornym, zdecydowanym, stawiać czoło przeszkodom, cierpliwie i konsekwentnie dążyć do celu; Șām $w$ șām $w$ foțor 'a-șsənșarāye ('Po długim poście musiał się zadowolić zjedzeniem jaszczurki')34.

Treść szeregu przysłów stanowi apel o zachowanie tajemnicy, aby nie doszło do sytuacji, gdzie żal nie pomoże: Ğawfo təsa' bardūšat tabīh $w$ kəlme mā yțīq yhalli fiyā ('Jego brzuch pomieści garnek jadła, ale jednego słowa nie może w nim [brzuchu] zachować') 35 . W każdym przypadku niepotrzebne ujawnienie informacji, której biesiadnicy nie spodziewają się, nie należy do dobrych manier. O takich, którzy nie mogą się nie wypaplać, rozplotkować, mówi się: $B \bar{a} z$ b bẹzatū ('Zniósł swoje jajko'), Sūmū mā yabqa fiyū ('Nawet czosnek [który zjadł] wypluwa'), Qaššar al-ḅezza ('Obrał jajko'). Jednak do chwalebnych zwyczajów należy to, że kiedy ze sobą rozma-

33 Takie powiedzenie słyszy się od muzułmanów, którzy nazywają chrześcijan „świniami”. Koniec Wielkiego Postu zazębia się z początkiem wiosny. Chrześcijanie zaś, komentując wielożeństwo u muzułmanów i co za tym idzie dużą liczbę dzieci, używając określenia: Wlād flān kamā bəzər al-pərpāre ('Tyle rodzi dzieci, ile portulaka nasion').

34 Chodzi o Post Wielki. Przenośnia: z biedy nie było go stać na zjedzenie mięsa zwierzạt hodowlanych. U mieszkańców Mārdīnu, gdzie - przypomnijmy - chrześcijanie stanowili połowę mieszkańców, spotyka się dziewięć przysłów odnoszących się do obyczajów chrześcijańskich: 1- Mā dām əl-h̆anzīr șāyəm - əš-šste dāyəm ('Dopóki świnia się pości, zima trwa'), 2- Ğum'at al-arb'inn: nəksər al-'adm, yoțla' barīr ('Wielki Piątek": łamiemy kość, a okazuje się, że jest pusta'), 3- Ahad əššsa'ánīn: nașbəg

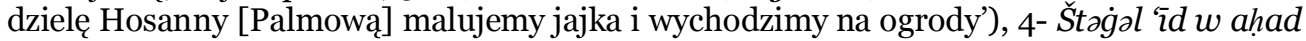
$w$ lā tzht wał'), 5- Id a barrahıt** - farrah̆bt ('Z nadejściem Chrztu Pańskiego, owce się cielą'), 6Șōm ən-nașāra țwīl $w$ 'arìd wal-'əryān mā ylahhıq yəktəsī ('[Wielki] Post chrześcijan jest długi i szeroki, a nagi nie zdaży się okryć'), 7- Yā̉kal ballo' $w$ yəqra fal-lāhūt ('Je ballo**** i czyta Biblię'), 8- Šarrāb al-'araq - bētū htaraq ('Alkoholik zrujnował swoją rodzinę'), 9Qālū la šarrāb əl-'araq: Bētək htaraq! Qāl: Otlū al-fənğān ('Mówili do alkoholika: Twój dom się rozsypał. Odpowiedzial: Napełnijcie szklankę'). *Wielki Post trwa siedem ciągłych tygodni. Polega na niespożywaniu jakichkolwiek produktów pochodzenia zwierzęcego; **Od asyryjskiego czasownika bārē $\underline{h}$ (błogosławić) często powtarzanego w liturgii Swięta Chrztu Pańskiego; ${ }^{* * *}$ Ballo ${ }^{*}$ - potrawa popularna u chrześcijan w okresie postu: do ugotowanej kaszy pszennej dodaje się smażoną do zrumienienia cebulę i koncentrat pomidorowy.

35 U mieszkańców Mārdīnu podobnie: Ywassa' $f$ ğōfū tanğara, $w$ mā yṭ̄q ywassa kalām ('Jego brzuch pomieści garnek, ale nie pomieści słowa'). 
wiają osoby poważne i poważane, a nagle słuchacz chce coś wyjaśnić lub dodać, przerywa rozmówcę w nader grzeczny, delikatny i kulturalny sposób: Ksər kalāmək bəs-səkkar ('„Łam” swoje opowiadanie cukrem')36.

W stosunku do osób, które w sytuacjach wahania się i braku stanowczości do podjęcia trafnej i logicznej decyzji, są w usterce, nie mogą dokonać wyboru, słyszy się powiedzenie: Wəqə' $f i$ bāzār al-batțīh ('Wpadł w targowisko melonów'). Wobec tego, którego szczęście opuszcza, reprezentuje postawę pasywną, nie zaszkodzi ani pożytku z niego nie ma, nie potrafi polegać na siebie, szuka oparcia u innych, i choć może on z kimś współdziałać, ale niebawem psuje to, co zrobił - stosuje się zwroty: All la mā yhammər $w$ ykammal fi 'ìdēnū ('Bóg sprawia, że na jego ręce nawet fermentacja nie zachodzi'), Yəšbah baqarət əz-zare - təh̆lab w t-kəbb əl-ḥalīb ('Jest podobny do krowy - daje mleko, ale je rozlewa'). A jeśli z byle jakiego powodu denerwuje się i traci opanowanie, wtedy spełnia on powiedzenie: Yəh̆tənəq mən šərbət may ('Nawet łyku wody nie może połknąć').

O osobach żyjących w dysharmonii i niezgodzie, jeden drugiego nie toleruje i za błahą rzecz wszczynają kłótnię i nie zależy im na porozumieniu i pojednaniu, mówi się: Flān $w$ flān kamā-s-səkkīn $w$ l-ğabne ('Oni są wobec siebie niczym nóż i ser'). A w sytuacji zaistnienia rzeczywistych niesnasek i wzrostu napięcia między nimi, gdzie może dochodzić do trwałej niechęci i gniewu, słyszy się powiedzenia w ostrzejszym tonie, przyjmowane niczym wyzwanie na pojedynek: Safratək mā bərdat qaddāmī ('Twój poczęstunek dla mnie stracił ciepło'), Tayrūh yəqta' karmī? ('Czyżby zniszczy on moją winnicę?’). Tak czy owak Kol wāh̆d yə'mal b-aṣlū w halībū ('Każdy postępuje według swojej natury i [matczynego] mleka37').

Do niedawna w większości krajów Bliskiego Wschodu osoby potrzebujące pomocy były zmuszone zdać się jedynie na siebie, przy czym narzekanie było zjawiskiem nieznanym: Ollī mā yākal əs-sūm, mā yə'rəf ta'mū ('Kto nie jada czosnku, nie zna jego smaku'). Taka fraza odnosi się też do osób, które doznają krzywdy nie zawsze ze swojej winy. Z drugiej strony zdarza się, że ktoś nie wyciąga wniosku z błędu, który popełnił, a nawet powtarza go: Yənqəhər mən ən-nār - yənfəh fəl-ṃay ('Obraził się na ogień - dmucha w wodę')38, Yhottt al-lahəm qəddām oș-ṣannōra ('Kładzie mięso przed kotem'). Jednak zawsze on sam ponosi odpowiedzialność za swoje czyny: $\bar{E} \check{s}$ tozra' - hāk tahṣad ('Zbierasz to, co siejesz'), Šs al-tabahtū $-r \bar{u} h$ kəll mənnū ('Jedz to, co sam ugotowałeś')39, Oll mā yākəl əs-sūm, mā yəğ̄ rīha mənnū ('Kto nie zjada czosnku, nie wyczuwa się z niego zapachu'). Ważne jest, aby umieć sobie dobierać odpowiedniego partnera, aby nie

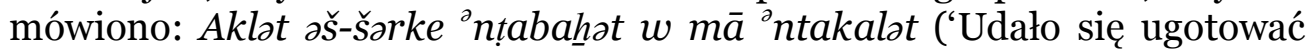

${ }^{6}$ Zwrot występuje także w dialekcie Mārdīnu.

$37 \mathrm{O}$ roli matczynego mleka jako symbolu i wzorca w kulturze ludowej, zob., Abdalla (1994: 28-40).

$3^{8}$ Podobną myśl wyraża mardińskie powiedzenie: Yəhtərəq təmmū mən nafh əl-hadīd -

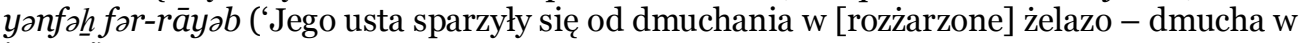
jogurt').

39 Odpowiadają im w przysłowiach Mārdīnu: Oll toṭbəh mənnū - tākəl məmmū ('Zjesz to, co ugotujesz'), Ěš mā ḥațtêt fot-țanğara - tākəl ('Zjesz to, co do garnka włożysz'). 
wspólną potrawę, ale nie udało się jej zjeść'), Yləmm bəl-ma laqa w yəkəbb bəl-məg்rafe ('Zbiera łyżką, a wylewa nabierką')40.

Każdy podwładny pragnie, aby przełożony dbał o swoją trzodę, bronił jej interesów, podniósł na duchu, mądrze prowadził i opiekował się potrzebującymi. Nie z winy społeczeństwa zaniedbanie tychże obowiązków może wywołać niezadowolenie i zaniepokojenie, a nawet destabilizację i chaos. Główną odpowiedzialnością za taki stan rzeczy obarcza się beztroskliwego i indyferentnego przywódcę, gdyż: Os-Samake mō təh̆rab alla mən rāsā ('Ryba psuje się od głowy')41, Yəšbah al-ǧōze: izā mā tqaššar, mā yəntəkəl ('Jest podobny do orzecha: jeśli się nie rozłupie, nie da się go zjeść')42. A po „obłupieniu” i być może „przekupieniu” albo zaprzyjaźnieniu się z nim, co wiąże się z poznawaniem jego tajemnic i punktów słabych, wtedy określa się go: 'Ağìn $w$ h bayz 'ìdi huwwe ('Jest jak ciasto i chleb w moich rękach'), czyli mogę go kształtować do woli i jest mi nieskończenie posłuszny. Jednakże dopóki tyrani i despoci rządza, Āzāhowie radzą postępować asekuracyjnie, by nie budzić ich gniewu i nie dać powodu do zemsty: Māt hṣān alamīr - șār lu 'azā gbīr; māt al-amīr - nēs mā tola' halfū ('Koń emira zdechł - miał wielką stypę; emir zmarł - nikt nie poszedł na jego pogrzeb’). A niektórzy przypominaliby, że przecież Ol-Zabbēne thallaq 'al-dammūš ('Mucha siada na to, co słodkie').

\section{Oblicza gościnności i złych nawyków}

Przysłaniem wielu przysłów jest przypominanie gospodarzy o niejako oczywistym u ludzi Wschodu poczuwaniu się do obowiązku okazywania serdeczności gościom i podawania im najlepszych potraw, nawet jeśli członkowie rodziny gospodarza nie najedzą się tym, co zostaje lub będą musieli przygotować sobie inną potrawę, uważaną za gorszą. Gościnnego i hojnego gospodarza Āzāhnowie chwalą: Ləqmot səmmū mì luhū ('Kęs w jego ustach nie jest dla niego'). A kiedy do mieszkania Āzāha zagląda ktoś w chwili podawania lub trwania posiłku, usłyszy on w zachęcającym tonie: Hamētək thıbbək ('Twoja teściowa cię lubi'), co jest równoznaczne z zaproszeniem i częstowaniem się tym, co znajduje się na stole. Jednak zamiar wydania przyjęcia, zwłaszcza jeśli gość jest osobą wpływową, nie zawsze jest bezinteresowny. Zakłada się bowiem, że skoro Әs-Səmm yākol w l-'ēn təstəḥ̄ ('Usta jedzą, a oko [ugoszczonego] się wstydzi'), gość, który przyjął zaproszenie, tym samym przyjął na siebie zobowiązania i nie wypada mu odmówić prośby ze strony gospodarzy. Nie jest wykluczone w takiej sytuacji, że gość, który, być może, niezgodnie z oczekiwaniami i mało entuzjastycznie

40 Do pewnego stopnia korespondują z nimi przysłowia mardińskie: Әl-Ləqme wașlat lassəmm ('Kęs dotarł do ust') [czyli nie zdążył skorzystać z tego, co wypracował], Kətrū l-ğăăg

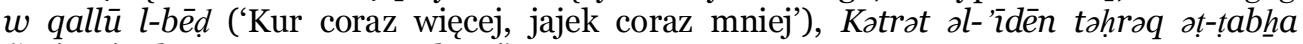
('Więcej rąk - potrawa przypalona').

${ }^{41}$ Identyczne pojawia się w przysłowiach Mārdīnu.

${ }^{42}$ U mieszkańców Mārdīnu: Әl-Ğōz allī mā yənkəsər - mā yəntəkəl ('Nieobłupanego orzecha nie da się zjeść'). O beznadziejnym, nieudolnym i nieporadnym: Lā ğăğū yḅị $w$ lā dīkū yșīh ('Ani jego kury jaj nie znoszą, ani jego kogut nie pieje'). O kłótliwym, szorstkim i nieokrzesanym: Mən dəhnū mā yəntəkəl ('Tluszcz jego [potraw] nie jest jadalny'). 
poszedł gospodarzowi na rękę, usprawiedliwi swoje bądź co bądź zaangażowanie w nieco dowcipny i dwuznaczny sposób: Mən əl-mağbūriyye wāhəd yākəl lah̆əm ğēğ ('Z obowiązku ktoś jada kurze mięso')43. Natomiast, jeżeli takowe przyjęcia powtórzą się, gdyż obu stronom zapewniają korzyści, wówczas gość spełnia powiedzenie: $Z \bar{a} q$ ot-ta'me ('Spróbował smak'), czyli do tego stopnia polubił 'smak' tych przyjęć, że stało się to niejako zwyczajem, co jest postawą negatywną.

Treść stosunkowo szerokiej galerii przysłów stanowi ostrą krytykę tych, którzy mają złe nawyki, np. łapczywość i pęd do nieograniczonego posiadania: Yākəl əl-ğamal w homlū ('Zje wielbłąda z tym, co wielbłąd nosi'), əlĞōf šəb'ane w l-'ēn ğū'ane ('Brzuch syty, a oko wciąż głodne'), Fatahtūk yā ğôf - harrabtūk yā bèt ('Otworzyłem cię, brzuchu - zrujnowałem cię, domu')44, Әl-Akəl mō lək, qay al-ğôf may lək ('Jedzenie nie jest twoje, ale przecież żołądek jest twój'), Mā yhallì hamīre fi mah̆mara ('On nawet drożdży nie zostawi w drożdżowni')45. Chyba jednak najbardziej trafny i wymowny, choć dosadny i jaskrawy opis obżartuchów i tych, którzy wykorzystują każdą okoliczność dla prywatnych celów, oddaje przysłowie: $\mathrm{Ka}$ mā l-mənšār - yakəl 'a-ț-tal'a w'a-n-nazle ('Podobnie jak piła, pożera zarówno w jedną, jak i w drugą stronę') 46 . Sytuację, kiedy gospodarz nie spełnia swoich obowiązków wobec gości, choć stać go na to, a to, co im podaje do jedzenia, nie wystarcza na zaspokojenie głodu, określa się: Taksīr ə⿳̆冖̆-ğabas mā ybarrəd əl-qalb ('[Samo] krojenie arbuzów serca nie ochładza')47, Šəmm w lā tzūq ('Powąchaj, ale nie jedz')48. Zaproszony w każdym

43 Kurze mięso uchodzi za rarytas.

44 Porównaj z sumeryjskim powiedzeniem w arabskim tłumaczeniu (Bāqir 1967: 124): Yad b-yad - t'ammor bèt, batn b-baṭ - yharrab bèt ('Ręka w rękę zbuduje dom, żołądek w żołądek zrujnuje dom'). O tym, kto w wyniku jedzenia ponad miarę zaokrągla się, Āzāh mówi: Karenfeh , yākal w yənfah ('Karenfeh je i dmucha'). Wyraz karenfeh jest nieznanego pochodzenia, oznacza człowieka grubego, brzuchatego, tłustego (Bašī 1953: 254).

45 Mardińska wersja: Dawwaqnā l-hamīre ('Doszło nawet do tego, że musieliśmy zjeść zakwas') - tak mogą mówić gospodarze o niespodziewanym gościu, którego utrzymanie spowodowało wyczerpanie wszystkich zapasów żywności.

${ }^{46} \mathrm{~W}$ przysłowiach Mārdīnu znajdujemy następujące: Ollī mā yākal hall, baṭnū mā yəğa ${ }^{6} \bar{u}$ ('Kto octu nie zjada [pije], tego brzuch nie boli'), Әz-Zabbēne təqa' $f$ dann al-'asal - tnağğəsū ('Mucha, która wpadnie do beczki miodu - skaże go').

47 Określenie: $M \bar{a}$ ybarrad al-qalb, spotykane także w innych arabskich dialektach wschodnich, jest prawdopodobnie dosłownym tłumaczeniem asyryjskiego odpowiednika w dialekcie Ṭūr 'Abdīnu: Lak māfăh u lēbō. ('Nie satysfakcjonuje serca'), oznacza, że czegoś było zdecydowanie za mało.

${ }_{48} \mathrm{Na}$ temat gościnności mieszkańcy Mārdīnu znają takie powiedzenia: Ollī yḥıbb al-‘əšre - yta“am al-labb w yākal al-qəšre ("Kto lubi towarzystwo, podaje miąższ, a sam jada skórkę’), Әl-Qahwe sōda w tbayy dọ əl-wəčč ('Kawa jest czarna, ale wybiela twarz') [to znaczy, że gospodarz nie dozna wstydu], Ğū' $f$ bētək səne, $w$ əkrəm șadīqək yōm ('Głoduj w swoim domu rok, abyś mógł ugościć przyjaciela jeden dzień'), Yā rabb, b`asalnā dẹf 'azīz, hatta nākal 'alā wəčču hamis ('Boże, wyślij nam drogiego gościa, abyśmy dzięki niemu jedli hamīs*'), Qəllāyət al-qaliyye - toțla' məstahye ('Patelnia do podgrzania qaliyye ${ }^{* *}$, będzie zawstydzona') [ponieważ objętość qaliyyi skurczy się i może nie wystarczyć dla gości]. A w przypadku organizowania przyjęcia, uczestniczyć w nim wypada tylko zaproszonym, aby nie tracić szacunku mieszkańców: Ollī yrūh balā șyāh, yəq'ad balā bsāt ('Kto pójdzie bez zaproszenia, usiądzie na gołej ziemi’) [to powiedzenie świadczy o miejskim trybie życia mieszkańców Mārdīnu; w wiejskim środowisku w każdym przyjęciu udział biorą zwykle 
przypadku powinien zachowywać się zgodnie z przyjętą etykietą, by nie mówiono o nim: Әড̌-Šārab qabl at-țălab - mal'ūn ('Ten, kto pije przed tym, kto o picie prosi - wyklęty'). Powinien też być odpowiednio ubrany; wśród mieszkańców Āzah znana jest przygoda, którą streszcza powiedzenie: $\partial l-$

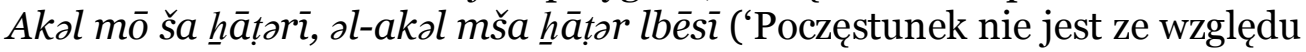
na mnie, lecz ze względu na mój strój’): obecny na przyjęciu nie został zaproszony na poczęstunek, czyli $M \bar{a}$ waqə' šì taht ẓrāsū ('Nic nie wpadło pod jego zęby'). Zażenowany opuścił biesiadników. Dowiedziawszy się, że powodem niezapraszania był nieodpowiedni strój, na drugi dzień ubrał się elegancko i jak tylko pojawił się na biesiadę, został zaproszony do Səfrot ta'm w ta'm ('Stół z wieloma smakołykami'), czyli otrzymał to, co tylko dusza pragnie. I być może po tej uczcie chodził i chwalił się: Ot-Ta'me bəqət fi səmmī ('Smak nadal tkwi w moich ustach').

\section{6 'Chleb' i jego magiczne i symboliczne znaczenie}

Chleb towarzyszy człowiekowi odkąd stał się rolnikiem. Istnieje zgodność, że najwcześniej ta cezura miała miejsce na terenie Mezopotamii, około 12 tysięcy lat temu. Tam, w części południowej, powstały pierwsze skupiska, które w okresie sumeryjskim przekształciły się w miasta ze świątyniami i pałacami. Najstarsze informacje o zbożach i ich magazynowaniu, o młynach i typach mąki, o fermentacji ciasta, piecach chlebowych i rodzajach chleba, o procesie słodowania ziaren jęczmienia i gatunkach piwa, znajdujemy w mitologii sumeryjskiej, uważanej za matkę wszystkich mitologii. Warto przypomnieć, że akadyjska nazwa pieca chlebowego 'tanuru' upowszechniła się po lekkiej modyfikacji prawie na całym Bliskim Wschodzie, w Azji Centralnej i Północnej Afryce.

Chleb uchodzi za pożywienie doskonałe, biorąc po uwagę logiczny ciąg etapów jego otrzymywania, a także ze względu na właściwości odżywcze, funkcjonalne i organoleptyczne. Podkreślić należy, że ponad połowa ludzkości naszego globu zachowała pierwotną postać chleba plackowego, a w wielu regionach stanowi produkt najważniejszy, bezkonkurencyjny, można by rzec: potrawę główną. Na Bliskim Wschodzie chleb jada się z ryżem, makaronem i kaszami, jest pierwszym pokarmem, który przychodzi na myśl zarówno głodnemu, jak i temu, który chce głodnego karmić. Nic więc

wszyscy, bez zaproszenia]. To, co potwierdza wiejski tryb życia Āzāh̄ów jest powiedzenie przypominające obyczaje przodków: Ğa ywaddī an-nār $w$ yrūh ('Przyszedł tylko po ogień i pójdzie sobie') [nagłe wpadanie sąsiada, by szybko zabrać ogień do podpalenia ogniska praktykowano zanim poznano zapałki]. Praktyka znana autorowi z okresu dzieciństwa. ${ }^{*}$ Hamīs - nazwa potrawy popularnej u Beduinów także pod nazwa tirīd: na wyłożone na półmisku świeżo upieczone przaśniki wlewa się kawałki ugotowanego mięsa i jada się rękoma. **aliyye - duże kawałki mięsa świeżo zabitej, specjalnie utuczonej krowy lub owcy, soli się i tak długo gotuje się w dużych kotłach, aż zgęstnieje; zawarta w kościach i chrząstkach żelatyna i całkowite wyparowanie wody powodują, że masa konserwuje się. Jest to jeden z ważniejszych zapasów produktów spożywczych w Țūr 'Abdīnie. Spełnia kryteria znanych obecnie w krajach uprzemysłowionych potraw „ready to eat”. Wystarczy lekko podgrzać. 
dziwnego, że stał się on symbolem wszelkiej żywności i zajmuje pierwsze miejsce także w przysłowiach ludowych 49 .

\section{(1) 'Alā wəčču nākol h̆bayz5o.}

'Dzięki jego obliczu jemy chleb'.

Określenie odnosi się do osoby, której nagłe pojawienie się lub też sama fizyczna obecność przynosi powodzenie w konkretnej sytuacji lub przedsięwzięciu. Najczęściej tym mianem określa się nowo narodzone dziecko, jeśli jego przyjście na świat zbiegło się z poprawą warunków życiowych rodziny bądź osiągnięciem przez któregoś z jej członków namacalnego sukcesu zawodowego, naukowego lub życiowego. Osoba tak określana jest uważana za mającą nieprzeciętną urodę, bez względu na płeć. Taki zwrot słyszy się również w stosunku do narzeczonej lub narzeczonego, pana młodego lub panny młodej, kiedy jednej z rodzin lub obu rodzinom powiedzie się lepiej w okresie trwania narzeczeństwa lub po zawarciu związku małżeńskiego.

\section{(2) Bātōye mō tabqa 'at-tannūr51.}

'Bāțōye nie zostanie na piecu'.

Szerokie zastosowanie tego zwrotu obejmuje różne sytuacje życiowe i zawodowe. Używa się w celu uspokojenia i zaniechania pośpiechu i każe wierzyć w przeznaczenie, np. kiedy - w opinii rodziców i krewnych - córka przekroczyła wiek zamążpójścia. W innym przypadku jest pouczeniem o konieczności samokontroli, dbania o rodzinę i pilnowania tego, co się posiada.

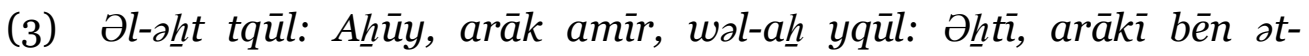
tanānīr52.

'Siostra mówi: Bracie, widzę żeś emir, a brat mówi: Siostro, widzę cię przy piecach'.

Powracający do rodzinnych stron po długiej nieobecności zauważył awans społeczny i prestiż brata, podczas gdy siostra wciąż zajmuje się wypiekiem chleba. Współczując pokrzywdzonej siostrze, ku swojemu niezadowoleniu, przybysz musiał przyznać istnienie niesprawiedliwego podziału obowiązków, dyskryminującego kobietę. Powiedzenie nosi duży ładunek żalu. Ma jednak szerszy wydźwięk społeczny, wskazując trudniejszą drogę kobiety do awansu i uwarunkowania, które promują mężczyznę, po części dotyczy to także żyjących w świecie islamu społeczności chrześcijańskich.

(4) Ollī yākal ḩbayz əs-sulțān - lazəm yəżrəb b-sēfū53.

49 Hənța allā ščr? - pytający chce wiedzieć, jak sprawa się zakończyła; jeśli usłyszy hənța, to pozytywnie, a jeśli usłyszy ščr - negatywnie.

50 Takie same przysłowie występuje u mieszkańców Mārdīnu.

${ }^{51}$ Wersja mardińska jest kompletniejsza: Bātōye mō təbqā 'alā dahər tannūr: aw yākəlā kalb aw yāksılā sannōr ('Bātộye nie zostanie na piecu. Albo zje ją pies, albo kot').

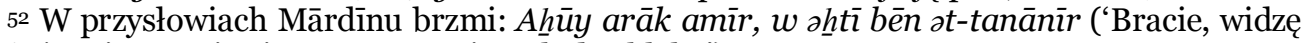
żeś emir, a moja siostra - przy piecach do chleba').

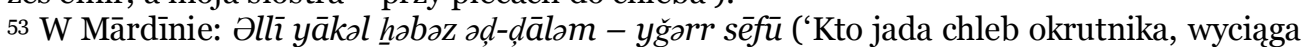
[na siebie] jego miecz'). Jest to ostrzeżenie o konieczności trzymania się z daleka od de- 
'Kto jada chleb sułtana, powinien bić się jego mieczem'.

Powiedzenie uprzytamnia podwładnym, że ich status nakłada obowiązek zachowania nie tylko lojalności wobec władzy, lecz - można by rzec - także pogodzenia się ze statusem ludzi poddanych. Jest to zapewne echo dawnych czasów, kiedy prosty lud uważał, że władza pochodzi od Boga, dlatego trzeba być posłusznym. Jak wiemy, gdzieniegdzie taki schemat jest aktualny także dzisiaj.

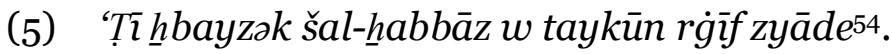

'Powierz swój chleb piekarzowi - otrzymasz bochenek więcej'.

Pouczenie o celowości powierzenia wykonania usług tylko fachowcom. To się opłaca nawet jeśli będą żądać wysokiej zapłaty. Apel ma szeroki kontekst, a posługiwanie się przykładem piekarza dowodzi rangi tego zawodu, a także ważnej roli chleba w żywieniu. Wobec osób nieudolnych i niedoświadczonych, którzy nie potrafią wykonywać jakiegoś zadania, stosuje się

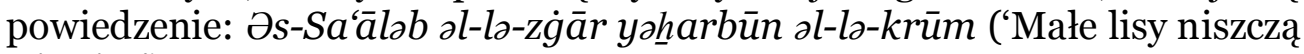
winnice').

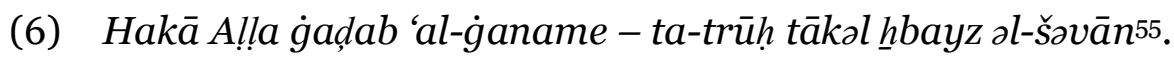

'Jeśli Bóg odwróci się od owcy, zje ona chleb pasterza'.

To raczej przykre w skutkach twierdzenie, rozumiane niczym przeznaczenie. Osoby, którym w życiu nie wiedzie się najlepiej, szukają wytłumaczenia w siłach nadprzyrodzonych. Wierzą, że to los odwrócił się od nich, zaćma opanowała ich umysł, co doprowadziło do utraty wszystkiego, czego dotychczas się dorobili. Dotąd dobrze im się powodziło, a w mgnieniu oka stali się biedakami. Próby odzyskania równowagi zakończą się niepowodzeniem, gdyż człowiek nie jest w stanie przeciwstawić się swojemu przeznaczeniu. Zapewne tego chciał Bóg, aczkolwiek nie wiadomo, dlaczego. Może nieszczęśnik wiódł niepoprawny tryb życia, czego nie było widać?

(7) Hal 'ağīn har tayšìl ṃay.

'Jest pewne, że to ciasto zwiąże wodę'.

Takie powiedzonko słyszy się w sytuacji pojawienia się znaków wyprzedzających wydarzenie.

(8) Hbayz w baṣal kamā l-‘asal.

'Chleb i cebula, niczym miód'.

spotów i nieprzyjmowania czegokolwiek od nich, nawet jeśli będzie to chleb. Jednak nie

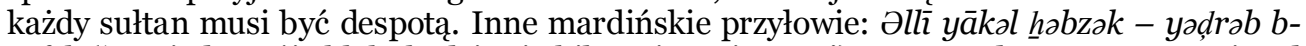
$s \bar{e} f_{\jmath} k$ ('Kto jada twój chleb, będzie się bił twoim mieczem'). Ma on odwrotne znaczenie od poprzedniego: kto nakarmi i pomaga innym, zaskarbi sobie ich przychylność i wdzięczność i może na nich liczyć.

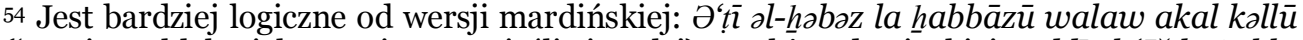
('Powierz chleb piekarzowi, nawet jeśli zje cały'), a także od egipskiej: Әdd̄ al-'éš la habbāzinnu walaw yāklū nașsū ('Powierz wypiek chleba piekarzom, gdyby nawet zjedli połowę').

55 W podobnym przysłowiu Mārdīnu kurdyjskie wyrazy: hakā ('jeżeli’) i šəvān ('pasterz') są zastąpione arabskimi, odpowiednio: $i \underline{d} \bar{a}$ i $r a \bar{a} \bar{c}$. 
Wyrażenie kryje uznanie dla ludzi, którzy choć jadają skromnie, są szczęśliwi. W ich oczach nawet najprostsze potrawy są smaczne jak miód, na który stać tylko bogatych. Ciekawe, że w tym zwrocie nie ma mowy o biedzie czy głodzie, jak w wersji popularnej wśród ludności arabskiej: Hubz w baṣal lağ-ğūân, atyab mon al-'asal ('Chleb i cebula dla głodnego są smaczniejsze od miodu').

(9) Hbayz al-ḩonta 'al-faqīr mō harāām.

'Chleb pszenny nie jest zakazany dla biedaka'.

Takie sformułowanie wypowiada się w sytuacji, kiedy ktoś biedny staje się nagle bogatym. Inne możliwe znaczenie: również biedny ma prawo jeść pszenny chleb, czyli poprawić swój byt materialny. Chleb pszenny jest symbolem awansu dla tych, którzy jadali chleb $\mathrm{z}$ innego surowca, np. $\mathrm{z}$ jęczmienia, a w latach głodu także $\mathrm{z}$ mączki żołędzi, często $\mathrm{z}$ domieszką sieczki.

(10) Hbayzū a'mā.

'Jego chleb jest ślepy'.

Zwrot przepojony goryczą i żalem wobec osoby, której starania w dobrej wierze nie przynoszą efektu. Jest współczuciem wobec niej. Ludzie nie zauważają tego, co ona robi, chciałoby się powiedzieć, odwracają się od niej, nie odwdzięczają jej się tym samym. Jej wysiłek idzie na marne.

(11) Hbayzū 'alā rokbətū kamā l-'oṣma!ḹī56;

'Trzyma chleb na kolanach jak Osman'.

W tym wyrażeniu komunikuje się rozczarowanie wobec Osmanów, którzy dopóki byli w potrzebie, robili wrażenie miłych, wdzięcznych, doceniających dobroć, chętnych do odwzajemniania się tym samym. Jednak okazało się inaczej. Po otrzymaniu tego, o co zabiegali, nagle odwrócili się plecami. Teraz udają, że nic się nie stało. Ale odtąd nie wolno im ufać. Są, jak głosi

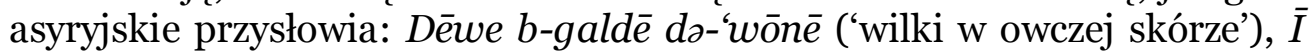
malhațēe ‘al barkōtayyē-yō ('swoją sól noszą na kolanach'). Chleb i sól na ziemi to profanacja. Niemal identyczne powiedzenie znajdziemy w Egipcie (także ten kraj był pod tureckim panowaniem): $\bar{A} \underline{h} ə r$ hidmət əl-guzz - sakter ('Wynagrodzenie za służbę na rzecz Oguza, to wynocha') (Taymūr 1986: 10).

(12) Hbayzū yəntəkəl.

'Jego chleb jest zjadliwy'.

Jest on gościnny, ma poczucie wartości i godności osobistej, przebywanie w jego towarzystwie jest pożyteczne, pouczające, jest zaszczytem, nie hańbą.

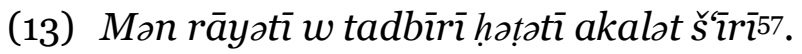

${ }^{56}$ Występuje w identycznym brzmieniu u mieszkańców Mārdīnu.

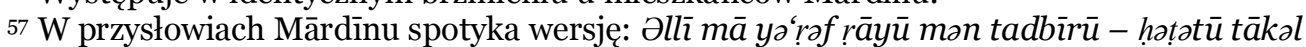
šì $r \bar{u}$ ('Kto strategii nie ma, jego pszenica pożre jego jęczmień'). 
'Z powodu złego gospodarowania, moja pszenica pożarła mój jęczmień'.

To samokrytyka i żal nad sobą za poniesione straty, zarówno materialne jak i moralne, z powodu zaniedbania, braku planowania wydatków i niestawiania czoła bieżącym problemom i wyzwaniom, które nasiliły się i zagrażają bytowi i stabilności życia rodziny.

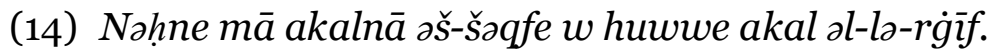

'My nie zjedliśmy kawałka, a on zjadł cały bochenek'.

Ta fraza wyraża żal: zanim on zjadł mały kawałek chleba, czym nie mógł zaspokajać swojego głodu, jego towarzysz zdążył, egoistycznie, zjeść całą resztę bochenka, zapominając, iż chlebem trzeba się dzielić.

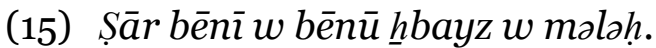

'Między mną a nim jest chleb i sól'.

Powiedzenie uświadamia, przypomina, akcentuje więź, zażyłość, przyjaźń między konkretnymi osobami, a także będące konsekwencją - zobowiązanie do przyjścia sobie z pomocą nawzajem w razie potrzeby. Wyrażenie jest też ostrzeżeniem bądź upomnieniem - wyrażonym łagodnym tonem - adresowanym do osoby, która zaniedbuje obowiązki w stosunku do kogoś, kto ma prawo oczekiwać interwencji, wsparcia, lojalności, uczciwości. Powiedzenie ma więc nieco inny kontekst aniżeli popularna w Polsce wersja: „Zjadłem z nim beczkę soli”, oznaczająca, że się kogoś dobrze poznało, ale raczej nie nakłada obowiązku odpowiedzialności za niego.

(16) Škavāyətū mā htaraqət 'ad-dawq.

'Jego przaśnik nie przypalił się na blasze'.

Takie stwierdzenie słyszy się w sytuacji, gdy ponagla się kogoś do podejmowania ważnego postanowienia czy decyzji. Jest apelem do bycia cierpliwym. Najczęściej słyszy się, kiedy w grę wchodzi np. wydanie córki za mąż $5^{8}$.

Na zakończenie przytoczę osobliwą historię, której czas i postaci nie są znane, jednak zrodziła powiedzenie z dumą powtarzane przez Āzāhów:

„Pewna samotna pani z Āzāhn najęła kilku robotników rolnych, aby zaorali jej pole. Wynagrodzeniem każdego miał być jeden bochenek chleba dziennie. Chcąc udowodnić sobie i innym, że również i kobieta potrafi być przedsiębiorcza nie gorzej niż mężczyzna, postanowiła prowokować oraczy

${ }^{8}$ Mieszkańcy Mārdīnu znają więcej przysłów z wyrazem 'chleb’ lub jego składnikami: Zawğ mən fahme - tayğīb h̆ həbəz w laḥme ('Mąż z węgla - zapewni i chleb, i mięso'), Həboz al-ğamīl ma'a walad al-ḥarām - d̦âyə' (Nawet chleb dziękczynny ze złym człowiekiem jest stracony'), Həbəz əl-lə-rğāl 'al-lə-rğāl - dayn ('Chleb mężczyzn jest długiem wobec mężczyzn'), Đllī yoțlab lahəm, trudūhu $w$ allī yoțlab habaz, rhamūhu ('Kto prosi o mięso,

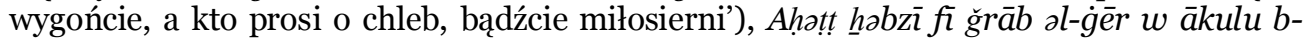
mənniyye ('Wkładam swój chleb w skarpetki innych i jem go z laski'), Ollī 'andu hənța ydaynūhu daqīq, $w$ allī 'ondu daqīq ydaynūhu h̆bbəz ('Mającym pszenicę pożyczają mąkę, a mającym mąkę pożyczają chleb'), Māt bābā wən-yamm əd-daq̄i ('Ojciec zmarł, a mąka się skończyła'), Abəhhh fi wəčču daqīq ('Wdmuchuję mąkę w jego twarz'), Madahnnā al-qatt - zabbal fal-lə-ṭīn ('Chwaliliśmy kota, aż narobił w mące'), Kall họnța əlā kayyāl ('Każda pszenica ma swojego mierniczego'). 
do maksymalnego wysiłku. Każdemu z osobna zaoferowała dodatkową zapłatę pod warunkiem, że pozostali się o tym nie dowiedzą. Dodatkową zapłatą miał być kawałek sera. Pracownik poczytywał ten gest za wyróżnienie i był przekonany, że pani tylko jego darzy względami. Wyrażając wdzięczność, przyobiecał, że da z siebie wszystko i będzie pracować jak najwydajniej.

Nadzorując przebieg pracy, energiczna gospodyni co chwila donośnym głosem wołała: Șāhəb šəqfət əğ-ğəbne yə'rəf ḥālō ('Ten od kawałka sera wie, o co chodzi'). Każdy z robotników rozumiał te słowa jako kierowane pod jego adresem o jeszcze efektywniejszą pracę. Oranie pola, które zwykle trwało cały tydzień, zostało rzekomo wykonane w ciągu trzech dni”.

Ze względu na dość nietypową postawę kobiety i pozytywne efekty jej przebiegłości, powiedzenie przybrało charakter przysłowia. Obecnie jest używane dla zabawy.

\section{Zakończenie}

Przysłowia ludowe stanowią część mowy codziennej i cechuje je trwałość, choć można się obawiać, że w dobie globalizacji stopniowo stracą na aktualności i znaczeniu. Wiele przysłów powstało niezależnie od siebie w zgoła odmiennych kręgach kulturowych, ale wyrażają one ten sam kontekst w innym sformułowaniu. Pomimo że okoliczności ich powstawania pozostają $\mathrm{z}$ reguły nieznane, szybko przekraczają pierwotne granice. Duże podobieństwo z przysłowiami Āzah i Mārdīnu znajdujemy w przysłowiach Ṭūr 'Abdīnu (Asmar 1991); jedne są oryginalne, inne adaptowane, przy czym każdy ma prawo potraktować je jako element własnej kultury i filozofii.

Troska o zachowanie tego segmentu literatury oralnej jest oznaką szacunku dla bezimiennych autorów; oni byli wnikliwymi obserwatorami, dobrymi poetami i mędrcami.

\section{Bibliografia}

Abdalla, M. 1994. Milk in the Rural Culture of Contemporary Assyrians in the Middle East. w: P. Lysaght (Ed.) Milk and Milk Products from the Medieval to Modern Times. Edinburg: Canongate Press.

Abdalla, M. 2004. Wild Growing Plants in the Cuisine of Modern Assyrians in the Eastern Syrian-Turkish Borderland. Journal of Assyrian Academic Studies, vol. 18 , no. 2.

Abdalla, M. 2008. The Fate of Āzah: An Assyrian Town in Ṭūr 'Abdīn, Turkey. Journal of Assyrian Academic Studies, vol. 22, no. 1.

Abdalla, M. 2013. Yüzyilin Ortalari ile I. Dünya Savaşi Arasinda Mardin ve Halki: Yabanci Misyonerlerin ve Eski Sakinlerin İzahlari. w: E. Ayvaz, A. Yilmaz (Eds) Mardin Tebliğleri: Mardin ve Çevresi Toplumsal ve Ekonomik Tarihi Konferansi. Istanbul: Hrant Dink Vakfi Yayinlari.

Asmar, Ğ. M. 1991. Hikam Az-zamān fi amtāal as-Suriān [Mądrości wszechczasów w przysłowiach Asyryjczyków]. Qāməšlī (Syria).

Bāqir, Ṭ. 1967. Muqaddima fì adab al-'irāa al-qadīm [Wstęp do literatury starożytnego Iraku]. Bagdad: Uniwersytet Bagdadzki.

Bār Armaltō, I. 1927. Salwā ar-ra ìdīn fi amțāl Mārdīn [Pocieszenie dla spragnionych w przysłowiach Mārdīnu]. Bejrut. 
Bašīr, A. 1953. Qāmūs fi al-lahğe al-azhēniyye [Słownik dialektu āzāhnskiego]. Qāməšlì (Syria).

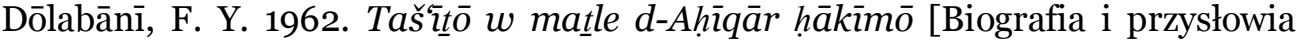
mędrcy Ahiqara]. Mārdīn.

Isḥāq, L. 1994. Amtāa min Bāzabde - 'arḍ wa taḥlīl [Przysłowia z Bāzəbde - przegląd i analiza]. Qāməšlì (Syria).

Jastrow, O. 1969. Arabische Textproben aus Mardin und Asex. Dans Zeitschrift der Deutschen Morgenländischen Gesellschaft (ZDMG). 119.

Maqsi, C. B-H. 2011. Hayat fë Azëx: Xalf l Farman $w$ fë waqt l Farman [Życie w Âzah przed i w latach holocaustu]. J. Bet-Şawoce (Ed.). Södertälje: Bet-Froso Nsibin.

Socin, A. 1904. Der Arabische Dialekt von Mōsul und Märdīn. Leipzig.

Taymūr, A. 1986. Al-Amtāâ aš-ša biyya [Przysłowia ludowe]. Kair: Al-Ahrām.

Tezel, A. 2003. Comparative Etymological Studies in the Western Neo-Syriac (Țūrōyo) Lexicon. Studia Semitica Upsaliensia 18, Uppsala Universitet.

Tronina, A. 2011. w: M. Starowieyski (Ed.) Apokalipsy syryjskie. Kraków: WAM.

Wittrich, M. 2001. Der arabische Dialekt von Azəx. Wiesbaden: Harrassowitz Verlag. 